\title{
B2B Customers Buying Behavior
}

\author{
Mieczysław Pawłowski \\ Onninen Sp.zo.o. \\ mieczyslar.parwlowski@onninen.pl \\ Zbigniew Pastuszak \\ Faculty of Economics \\ Maria Curie-Sktodoroska University in Lublin, Poland \\ z.pastuszak@umcs.lublin.pl
}

\begin{abstract}
Purpose - The presented paper aims to characterize the main differences and similarities between $\mathrm{B} 2 \mathrm{~B}$ as well as the commercial customers buying behaviors.

Design/Methodology/Approach - The authors' approach is based on the literature and research review, concerning the $\mathrm{B} 2 \mathrm{~B}$ customers buying behaviors. The authors assess buying behavior of professional clients.

Findings - Based on the analysis, we can find out that the use of electronic means of cooperation between the companies continues to grow in strength and dynamics. It seems that the distribution model, where the supplier runs his own B2B shop, maintains its position only in case of strong market players. Small and weak players will use the universal marketplaces. We observe growing "self-service with everything"; providers will pass on to buyers and systems, most actions which they can perform by themselves.

Practical implications - The outcome of the analysis can teach managers to act on the B2B electronic markets, how to organise the multi-channel sale systems and how these systems can be used by both, commercial and business customers.

Original value - The original value of the paper is that we have presented the general analysis of possible future expectations of B2B business customers, as well as those customers buying behaviors which regard to the use of the omnichannel sale.
\end{abstract}

Article type - Research and literature general review.

Keywords - B2B customers, omnichannel, value, e-commerce.

\section{Introduction}

Modern e-commerce sale between businesses (B2B) is changing as fast as trade between individual consumers (B2C). The development of the Chinese market and the global Internet companies, such as eBuy, Alibaba and Amazon in the B2B market, caught the attention of researchers, consultants and entrepreneurs on the specifics of buying behavior of professional clients. It was noted that the construction of B2B Customers
Buying Behavior 
IJSR 5 shopping portals for companies is similar to retail stores, which may suggest that the buying behavior of $\mathrm{B} 2 \mathrm{~B}$ customers can also be copied from the consumer behavior. The concept of organizational purchasing behavior has been presented by Webster and Wind (1972, with more than 1,000 citations). The authors define four main dimensions and mechanisms for the implementation of corporate purchases. The first one covers the external conditions, such as the behavior of suppliers, customers, authorities, organizations, employees and other stakeholders operating in the business environment. Another dimension is associated with the organization, its structure, strategy, resources and technology used. The third dimension of organizational buying behavior relates to activities of shopping center, its tasks and structure as well as skills and competence in the field of technology and decision-making. The fourth dimension is focused on individual people carrying shopping for companies, their powers and limitations (such as organizational and psychological). Model of Webster and Wind is presented in Table 1.

Studies on model making of purchase decisions in companies also appear in other publications (see Lingqvist et al., 2015) presenting the purchasing process of business

\begin{tabular}{|c|c|c|}
\hline Dimension & Description elements & $\begin{array}{l}\text { Elements available for the next } \\
\text { dimension }\end{array}$ \\
\hline $\begin{array}{l}\text { The Environment } \\
\text { The external environment } \\
\text { (physical, technological, political, } \\
\text { eeconomic, legal, and cultural) }\end{array}$ & $\begin{array}{l}\text { Suppliers, customers, authorities, employee } \\
\text { unions, trade associations, professional } \\
\text { groups, other companies, institutions }\end{array}$ & $\begin{array}{l}\text { Information about suppliers, } \\
\text { marketing and communication, } \\
\text { availability of products, general } \\
\text { business conditions, the values } \\
\text { and standards on the market }\end{array}$ \\
\hline $\begin{array}{l}\text { The Organization } \\
\text { The Organization and its } \\
\text { culture and climate (physical, } \\
\text { technological, economic and } \\
\text { cultural) }\end{array}$ & $\begin{array}{l}\text { Organization's technology; } \\
\text { Structure; } \\
\text { Objectives and tasks; } \\
\text { Members }\end{array}$ & $\begin{array}{l}\text { Technology process of purchase; } \\
\text { The organization of the department } \\
\text { and the purchasing process; } \\
\text { Tasks for shopping services; } \\
\text { Shopper team members }\end{array}$ \\
\hline $\begin{array}{l}\text { The Buying Center } \\
\text { Interpersonal determinants } \\
\text { of purchasing behavior }\end{array}$ & $\begin{array}{l}\text { Organisational and technological } \\
\text { constraints and available technology; } \\
\text { The structure of the department; } \\
\text { The tasks of the department } \\
\text { Profile of team members, objectives and } \\
\text { leadership }\end{array}$ & $\begin{array}{l}\text { Activities; } \\
\text { Interactions; } \\
\text { Sentiments }\end{array}$ \\
\hline $\begin{array}{l}\text { The Individual Participants } \\
\text { Motivations, cognitive structures, } \\
\text { personality, the process } \\
\text { of connection to the team, } \\
\text { the perception and its role }\end{array}$ & $\begin{array}{l}\text { The process of making purchase decisions; } \\
\text { Decissions process of individual and group } \\
\text { decision }\end{array}$ & Implementation of purchase \\
\hline
\end{tabular}

Source: Own calculations based on Webster and Wind (1972).
Table 1.

Organization purchasing model 
clients and analysed significant differences in relation to the process of purchasing made by individual consumers. The consultants of McKinsey Company developed a spiral model of corporate purchases, shown in Figure 1.

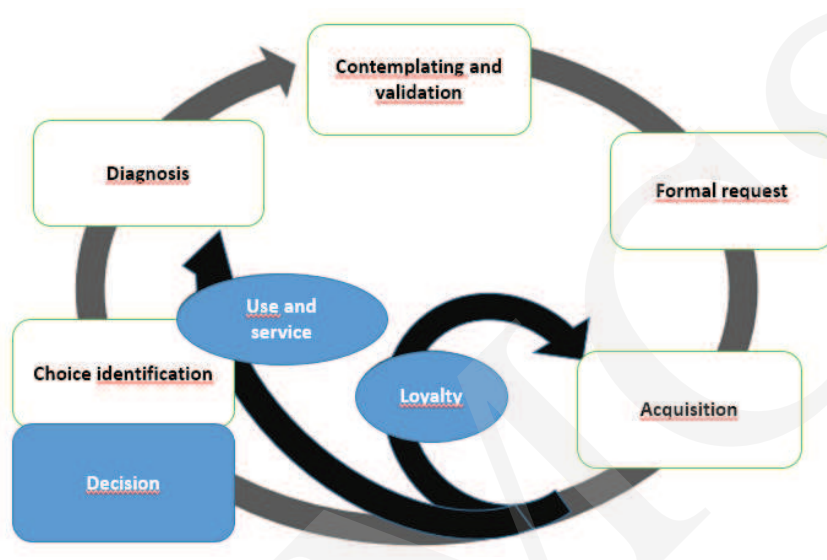

Source: Lingqvist et al. (2015).
B2B Customers Buying Behavior

In the online environment, sellers are better prepared to associate their offer to the demand of buyers in various stages of the process. There are used available tools to lead their purchase decisions much faster. On the basis of more than 100 B2B organizations, authors conclude that the company increased by $20 \%$ the number of potential customers, a $10 \%$ increase in the number of new customers buying products for the first time, and about $20 \%$ of the shortened time between registration of the contact and closing sales. The authors clearly distinguish the nature, and the differences between the purchases of the company and the purchase of the individual consumer. It is characterized by the following features: a large number of research before the product buying; careful examination of the technical specifications and the formal purchase procedures; analysis of the cost of the transaction; focusing, in particular, on product functionality; increasing the number of people participating in the procurement process, as well as requirements in relation to the sales representatives of the company offering solutions. They usually require from the sales representatives excellent technical preparation and knowledge of the business of the company to which they offer their products and even personal guidance for merchants if they are available on social network sites.

Interpersonal relationships one to one increasingly turn into relations one to many, and will have great significance also for the submission of requests for proposals and the final decision. Suppliers can never be certain that long-term relationships provide them with the order, because the relationship to other bidders are not directly visible. Moreover, contacts at other levels of decision-making can prevail and transfer the order to other bidders.

A report published on the website Traxpay.com shows that customers expect B2B purchase experience similar to those offered by Amazon (Amazon-like experience). 
IJSR 5

Professional clients, representatives of companies, compare their storefronts with Amazon.com site, which is a kind of benchmark. As better than Amazon - defined 17\% of corporate websites, and $48 \%$ - as inferior, even though in relation to the competition usually evaluate them as better or at least comparable. It seems that the Amazon site is seen as a model defining the direction in which the development of online trading systems should aim (traxpay.com, 2015).

A wider analysis of the differences between B2C and B2B markets from the point of view of marketing presents Wieczerzycki (2013). The author analyzes four groups of factors related to: 1) the duration of the interaction, 2) the perceived role and behavior of the customer, 3) B2C vs. B2B market structure and 4) the subject of interactions of marketing. Detailed analysis of these factors' groups author concludes that "[...] classically understood marketing dichotomy in B2B and B2C loses offered cognitive value. The differences in some cases disappear".

Demographic change generations of buyers and managers enterprises have a significant impact on the formulation and method of implementation of the purchasing procedures. Johnson (2016) makes comments on the perception of the business environment by people born after 2000 (Millennials). Companies offering products and services on the Internet are the first choice for a new generation of partners. In addition, they do not distinguish the offers for individual as well as for business professionals. They just use the whole resource and demand to take into account their habits. The author presents five areas in which there are observed significant changes. At first, he mentions considerable development of the omnichannel model along with the growing use of smartphones. Currently, Millennials take over more and more positions in companies ( $34 \%$ compared to $29 \%$ occupied by the Baby Boomers) expecting consistent service across all channels. Another important factor in running a business is to reduce costs in companies (up to $90 \%$ ). It causes that the current self-service offer turns into a full-service for both customers and employees. Another observation of the author concerns the linking application platform in the cloud. They result in a new, easier form of integration between systems of different partners and instant reach to the customer with multi-dimensional and full range of integrated partners that support payments, logistics and so on. What is more, globally available solutions allow quick services and platforms to be tailored to customer segments and profile business without hiring programmers or purchasing servers. All this causes a significant acceleration in the development of new business ideas, the most tested in the market B2C which now is ready for use in the $\mathrm{B} 2 \mathrm{~B}$ market.

Observations on the demographics were made by Snyder \& Hilal (2015) as well. They emphasize that there has been a significant change in the age of sale systems users. A clear difference was noticed in the group aged 18-34. In 2014, this group accounted for $18 \%$ among persons engaged in the search for business purposes. In 2015, it was $46 \%$. As a result, the influence of this group on the companies' activities and the environment is becoming more and more evident. The mindset of customers from this group and shaped ways of working will affect the structure of businesses with whom they cooperate. They expect, among other things, full-text search products, immediate reaction of a supplier in question, prefer a multimedia online communication between business partners (Figure 2). 


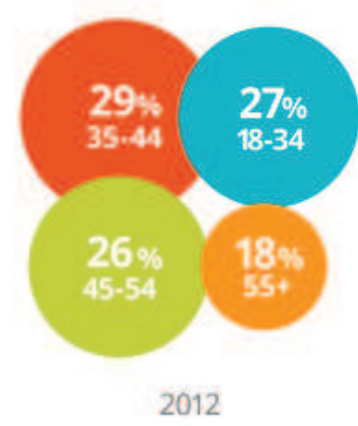

Source: Google / Millward Brown Digital (2014).
B2B Customers Buying Behavior

The buyers for the business move their behavior from the world of individual consumers. They expect the same functionalities in purchase for companies and a similar quality of service on the part of sellers. This position presents Kaplan (2015). She describes the changes in behavior and professional treatment of customers by the suppliers of a strong position portals like Alibaba and Amazon. Their entry into the professional market accelerated the transformation of purchasing systems. B2B portals were modeled on the online stores comparably to those designed for retail customers. In the construction of environments for professionals, as well as retailers, there has been highlighted the shaping of a positive customer experience throughout the purchasing process. This approach treats the person as a buyer, who has his/her expectations, experience and - at least to some extent - the will to perform unplanned purchases, sometimes being influenced by recommendations. The author also draws attention to the changing model of purchasing on the B2B market with a one-tomany to many-to-many model. This is confirmed by data from the market B2B of the Alibaba and the Amazon portals (Frost \& Sullivan, 2015). Being signaled change is that currently such tenderers do not supply the entire range of products, but also provide a platform for other suppliers. It becomes a source of virtuous growth of sales, according to the principle: more products attract more customers, and more customers attract more suppliers.

\section{Characteristics of the B2B market}

Data on B2B e-commerce market are difficult to access. Frost \& Sullivan (2015) estimate the value of the global market to sell online B2B model in 2020 to a value of about 6.7 trillion $\left(1\right.$ trillion $=10^{12}$ ) dollars, which will constitute $27 \%$ of the total market trade. The market value of the sales professional e-commerce can also be estimated on the basis of available data from the $\mathrm{B} 2 \mathrm{C}$ market. According to eMarketer.com (2016), global retail sales in 2016 will reach the volume of 22.1 trillion dollars. Predicted sales in 2020 will reach 27.8 trillion dollars. Online sales is estimated at $8.7 \%$, giving a value of 1.9 trillion dollars in 2016 . The estimation for 2020 is 4.1 trillion dollars, 


\section{IJSR} 5

Figure 3.

Retail e-commerce sales (USD bilion) acting $14.6 \%$ of the total. Thus, if the online B2B market is estimated as twice the size of the e-commerce in retail sales, it leads to a value of about 8.1 trillion dollars in 2020 (Figure 3).

\section{Retail e-commerce sales worldwide from 2014 to 2020 (in billion U.S. dollars)}

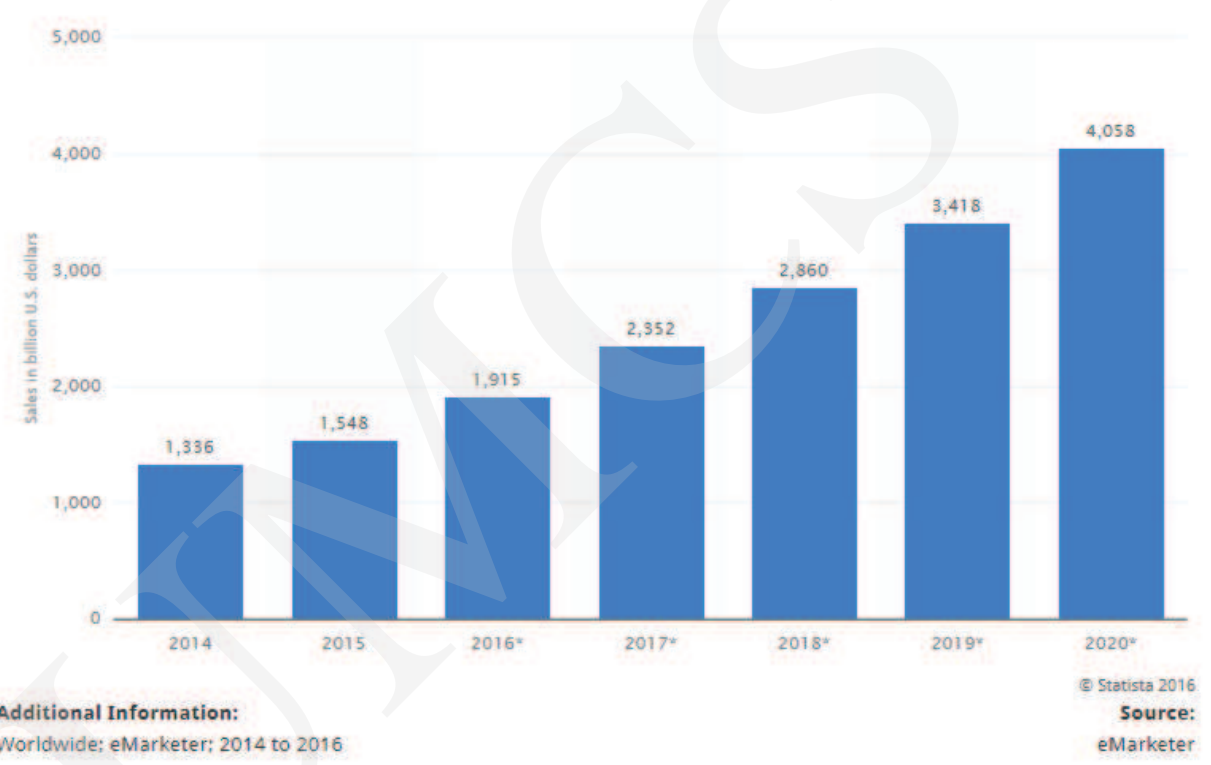

Source: emarketer.com, downloaded 20.10.2016.

United Nations Conference on Trade and Development (UNCTAD, 2016) provides data on the e-commerce market in 2015. The estimated online sales to retail customers was estimated to be worth 2.2 trillion dollars. While the value of the professional market is estimated at 19.9 trillion (Table 2). The largest retail market by the number of online shoppers is China, and the second - the United States. The B2B market is dominated by the United States with the estimated result of the sale of more than 6 trillion. The second place is occupied by Japan and China with sales of 2.3 trillion and 2.0 trillion dollars.

According to the Ecommerce Foundation (2016a, 2016b), online retail sales in 2015 amounted to 2.3 trillion dollars $\left(10^{12}\right)$, and in 2016 will reach 2.7 trillion US dollars, an increase of $17.5 \%$. Sales structure includes $62 \%$ of goods and $38 \%$ of services. In many cases it is difficult to assess whether the given data refer only to sales of goods or also include the sale of services. Data on sales of goods alone give such Statista (2016). Analyzing the categories of goods such as clothing, electronics and utilities, groceries and furniture and equipment - sales value for 2016 is slightly lower than that according to the report of Ecommerce Foundation and is worth 1.2 trillion dollars, giving a share of around $44 \%$ of sales of goods in total e-commerce market.

European B2C market value is estimated at around 2.59\% of GDP and amounts to 455.3 billion ( $10^{9}$, approx. 505 billion dollars), which is approximately $22 \%$ share of 
Pobrane z czasopisma International Journal of Synergy and Research http://ijsr.journals.umcs.pl Data: 26/04/2023 11:05:34

Top 10 B2C E-commerce Markets, 2015, ranked by number of online buyers

\begin{tabular}{|c|c|c|c|c|c|c|}
\hline & \multirow[b]{2}{*}{ Country } & \multirow{2}{*}{$\begin{array}{l}\text { B2C sales } \\
\text { S bilions }\end{array}$} & \multirow{2}{*}{$\begin{array}{l}B 2 B \text { sales } \\
\text { S billons }\end{array}$} & \multicolumn{2}{|c|}{ Onine buyers } & \multirow[b]{2}{*}{ Source ${ }^{m+m}$} \\
\hline & & & & $\begin{array}{l}\text { Number in } \\
\text { millions"* }\end{array}$ & $\begin{array}{l}\text { Annual spend } \\
\text { per buyer (S) }\end{array}$ & \\
\hline 1 & China & 623 & 2,078 & 413 & 1,508 & Ministry of Commerce \\
\hline 2 & United States & 511 & 6,072 & 166 & 3,072 & Bureau of Census and eMarketer. \\
\hline 3 & Japan & 114 & 2,380 & 57 & 1,994 & $\begin{array}{l}\text { Ministry of Economy, Trade and } \\
\text { Industry }\end{array}$ \\
\hline 4 & Germany & 52 & 966 & 41 & 1,270 & $\begin{array}{l}\text { Federal Ministry for Economic Affairs } \\
\text { and Energy }\end{array}$ \\
\hline 5 & $\begin{array}{l}\text { United } \\
\text { Kingdom }\end{array}$ & 174 & 709 & 38 & 4,539 & Interactive Media in Retail Group \\
\hline 6 & Brazilestar & 12 & 112 & 33 & 376 & E-bit \\
\hline 7 & $\begin{array}{l}\text { Russian } \\
\text { Federation }\end{array}$ & 23 & 700 & 30 & 758 & E-commerce Europe \\
\hline 8 & France & 72 & 600 & 25 & 2,916 & $\begin{array}{l}\text { Fédération du e-commerce et de la } \\
\text { vente à distance (Fevad) }\end{array}$ \\
\hline 9 & $\begin{array}{l}\text { Republic of } \\
\text { Korea }\end{array}$ & 48 & 969 & 22 & 2,120 & Statistics Korea (Kostat) \\
\hline \multirow[t]{3}{*}{10} & India* & 20 & 298 & 22 & 891 & $\begin{array}{l}\text { Internet and Mobile Association of } \\
\text { India }\end{array}$ \\
\hline & Top 10 total & 1,648 & 14,884 & 848 & 1,944 & \\
\hline & $\begin{array}{r}\text { Giobal } \\
\text { estimates } \\
\end{array}$ & 2,204 & 19,904 & $=$ & $\cdot$ & elMarketer (B2C) and UNCTAD (B2B \\
\hline $\begin{array}{l}\text { Sou } \\
20 \\
=0 \\
\text { Sou } \\
+\infty\end{array}$ & $\begin{array}{l}\text { UNCTAD, base } \\
\text { ived from Interne } \\
\text { in California Cer } \\
\text { fers to the source } \\
\text { B figure estimate }\end{array}$ & $\begin{array}{l}\text { on sources } \\
\text { user survey } \\
\text { for the Dis } \\
B 2 C \text { econd } \\
\text { ased on av }\end{array}$ & $\begin{array}{l}\text { din the tabi } \\
\text { ompiled by } 9 \\
\text { Future) and } \\
\text { c value (con } \\
\text { ge B2C-B2B }\end{array}$ & $\begin{array}{l}\text { nment agent } \\
\text { Russian Fed } \\
\text { d to United S } \\
o \text { for the othe }\end{array}$ & $\begin{array}{l}\text { with the exce } \\
\text { ation (E-comme } \\
\text { es dollars, usin } \\
\text { conomies amo }\end{array}$ & $\begin{array}{l}\text { tion of the United States of America (L } \\
\text { ce Foundation). } \\
\text { an annual average exchange rate). } \\
\text { g the top } 10 \text {. }\end{array}$ \\
\hline
\end{tabular}

Source: UNCTAD news (2016).

the global B2C online market. B2B market is estimated as twice the size, ie. approx. 1 trillion dollars.

The market value of B2B e-commerce in Poland was estimated in 2015 at 2.15 billion PLN (Bałkowiec, 2015). The analysis of the e-commerce market in Poland took Laskowski and Poszewicki (2015). The authors regarding the trends in the development of Internet commerce refer to commonly cited areas: mobile, personalization, multichannel and combining traditional sales and website. On the other hand, Malinowski and Senkus (2015) focused on the B2B market in Poland. Citing CSO data for the period 2012-2014, they estimated the value of the professional market at 2.2 billion PLN, of which $10-12 \%$ is B2B e-commerce, which gives a value of PLN 0.124 billion. According to the Eurostat (2015), the market value of B2B may be even ten times more than a similar value for the consumer market.

\section{Omnichannel - Multi-Channel Sales}

\subsection{Definition}

The concept of omnichannel is popular in the scientific literature (see eg. Lazaris, 2014; Deloitte, 2015; Yenna, 2015). It should, however, refer to the understanding of the omnichannel concept by managers. Rutkowski and Górazda (2016) define
B2B Customers Buying Behavior 
IJSR 5 omnichannel as a solution related to technology and strategy, which involves the synergy of online and traditional sales. Omnichannel marketing as consistent and penetrating the communications in multiple channels simultaneously, allows brands to tell a single story whenever the consumer desires to interact with them. As a result, the receiver provides a similar experience, regardless of the communication channel, if the device is enjoyed by him/her. This requires consistency and the creation of such a strategy of brand communication, which can be translated into all the channels in which it is present.

Currently, the consumer can come into contact with the brand at the point of sale, on the website of the brand in the mobile application, its channels in social media, television, outdoor advertising, press, etc. His/Her experience across all channels should be consistent and complementary. The television campaign may, for example, redirect him to social media, and social media to the website of the brand. Consumer can start buying product on a mobile device, and then move on to another device. What is more, there are many channels to choose from, and the customer can use them at the same time (e.g. the phenomenon of second screen - watching TV and using the mobile device at the same time). The main advantage of multi-channel marketing is greater brand exposure and easy access to its contact. Omnichannel allows you to reach consumers in multiple locations simultaneously and increases the reach of the brand. Marketing activities created in this way are also more consistent and reflect the creation of a consistent brand image.

Brand presence across multiple channels also provides more information about consumers and can better understand their behavior. It also requires a focus on data analytics and conducting research to accurately identify which devices customers use and when you are most likely to receive marketing messages.

The concept of omnichannel gains popularity as a model in trading companies. Bełcik (2014) refers to the research conducted by the Unity, the IT company (Unity, 2014). The company examined 25 stores of the category: DIY, household appliances and electronics, cosmetics, footwear, furniture and accessories, assessing omnichannel conducted to their businesses. According to a study, Polish shops are still far from widespread implementation of multi-channel strategy. There are a few market leaders and rising customer expectations, but the companies confine themselves to running the basic functions of an online store, leaving aside the full integration and improvement of channels.

\subsection{The scope and development of multi-channel sales}

The authors of the Forrester report (2015) present study business of customers in multichannel sales model. The study included 1,307 decision-makers from 750 companies from the USA, Europe, Latin America and Asia. The analysis shows that about 25\% of B2B customers buying products online were using the Internet to identify the offer. Interestingly, $33 \%$ of them start searching from retail stores, $26 \%$ use search engines, and only $17 \%$ on sites designed for business. Respondents estimate that a total time spent on the sites for the purpose of purchasing is increasing, compared to previous years, increasing the percentage of all purchasing activities performed online and the total value of purchases in this channel. 
B2B customers market demand is the main motivating factor for their companies to run multi-channel sales. Subsequent entries submitted in the ranking are the factors associated with the convenience of users and cost optimization (Figure 4).

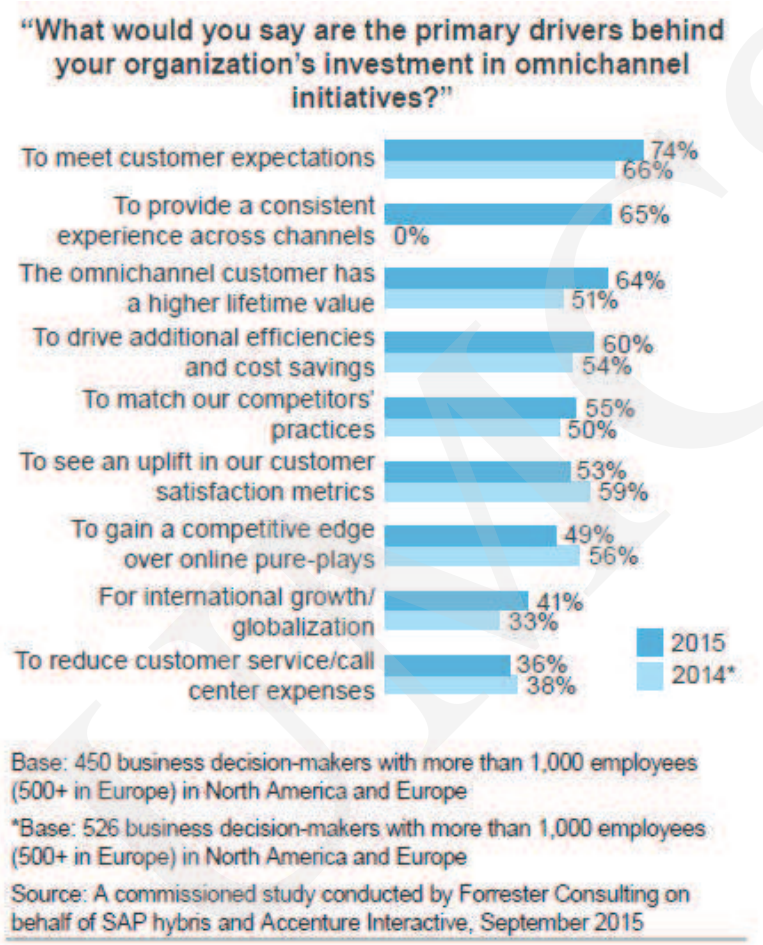

Figure 4.

Factors staggering companies to invest in multi-channel sales model

Source: Forrester (2015).

Respondents (professional clients) emphasize that they are willing to re-purchase from suppliers who have a transparent pricing system and offer consistently low prices, a wide range of products and excellent service. Through excellent service they understand individual approach, assistance during the purchasing and after-sales service. Each of these factors has accumulated more than $55 \%$ of the votes of participants. The second group of factors valued by clients includes personalized recommendations, various payment options and multichannel - these options are granted $33 \%$ to $39 \%$ of the votes. The authors also pay attention to the fact that it is necessary to use information technologies, agile processes, supporting purchases in real-time, as well as the employment of competent people capable of creating multi-channel systems involving customers, which consequently provide them with excellent shopping experience and build lasting relationships.

Interesting approach to multi-channel sales of WiFi technology presented Ważyńska (2015). The author notes that logging in to the WiFi network in retail chains, convenience stores, service points, hotels and restaurants provides marketers a multidimensional customer profile. Clear information about the free WiFi service, increases the prestige of the premises as well as attracts and encourages customers to take advantage of this free service. In order 


\section{IJSR} 5

to $\log$ into the network, customers must provide an e-mail. They also express consent to receive shipments marketing. Another option is to use a login profile with social networking, which further reveals customer data. In such a situation, it is easy to get to the age, gender or interests of the client. Additional marketing can induce the client to the activity in the media provider, which leads to building individual customer profile. Thus, the use of customer data to profile the media is no longer just a matter of professionalism of the marketing department of the service provider. The use of Social WiFi in the B2B customer segment is performed frequently on trade meetings, in hotels or in training.

Orrigo (2015) in her article draws attention to the phenomenon of the increasing use of applications on smartphones in B2B relationships. The conclusions from these observations include the statistics presented in Table 3.

On the other hand, Forte (2014) reports that about $7-10 \%$ of visits to B2B sites comes from mobile devices; over $52 \%$ of customers use smartphones to browse the products related to their business, $61 \%$ watch professional video clips, and $57 \%$ is constantly looking for content related to business - even during working hours. Customers use their smartphones to browse the reviews and recommendations (56\%), product information (55\%), comparing the characteristics of the products (50\%) and price (48\%). Suppliers shall respond to the needs associated with the increasing use of smartphones. Most of the providers surveyed (57\%) say that the move from the sphere of activities offline to online and virtual self. Many of them (44\%) say that B2B e-commerce adopts the best solutions for the consumer market in order to optimize the purchasing process.

\begin{tabular}{ll}
\hline Factor & Value \\
\hline & 176 million \\
& $73 \%$ of the total mobile phone market \\
Total USA population having smartphones & $55 \%$ of the US population have smartphones \\
\hline & $47 \%$ - Google search \\
The use of this smartphone to search & $19 \%$ - Amazon Mobile \\
\hline & $75 \%$ buyers of technical equipment have 2 smartphones \\
& $41 \%$ of them bought - during the last 6 months - a product which they had \\
& seen on the smartphone \\
& $40 \%$ watched it in our store after earlier seeing on the smartphone \\
& $36 \%$ of Internet users click on the ad technology products \\
\hline B2B customers & $45 \%$ of those surveyed by IDG, buying technical products, have identified \\
\hline & a positive impact of social media \\
& $72 \%$ of users are active on FB \\
Non-stop online, expressing the influence of & $30 \%$ of users have activated Instagram \\
socia media on smartphones & $20 \%$ use Twitter \\
\hline & Expenditure on advertising on mobile devices increased to 29.7\% (+ 5.1\% \\
& compared to 2014) of total advertising spending on e-commerce. This also \\
includes B2C\%.
\end{tabular}

Source: Orrigo (2015).

Table 3.

Use of smartphones in the community of professional clients 


\section{Buying behavior of clients in B2B sales 4.1. The use of different sales channels}

B2B Customers Buying Behavior

The E-Commerce Poland report (2015) was prepared on the basis of online questionnaires obtained from 50 representatives of 11 industries: electronics/appliances/photo, home and garden, computers and accessories, books and media, sport and tourism, automotive, clothing, cosmetics and pharmacy, hobby, children, food. A picture from the research emerges the perception sale of B2B e-commerce. Respondents indicate the use of the traditional sales channel supported website and catalog $(36 \%)$ or all channels $(44 \%)$. Only $4 \%$ of respondents use the traditional channel only. This may indicate the ongoing process of digitization of distribution model for professional sale. The most commonly used tool to assist traditional trade is electronic mail (89\%) and online catalog $(67 \%)$. Social media (33\%) and mobile application (22\%) are used much less frequently. Almost half of respondents $(47 \%)$ said that online tools have changed the way of communication with customers. A large number of respondents $(33 \%)$ noted an increase in the number of customers, a $20 \%$ increase in sales or even a change in the structure of the company. The majority of survey participants (74\%) indicate e-commerce as a key channel for business purposes, $41 \%$ use stationary shop and e-mail, and $37 \%$ perform shopping sales representative. Call Center and mobile applications accumulated the lowest number of votes $(22 \%$ and $15 \%)$. Answering the question "The prefered method of disposal" most respondents indicated e-commerce (78\%). Mobile application, call center and e-mail indicated $19 \%$ of study participants and stationary shop only $11 \%$. Apart from doing shopping and using multiple channels, personal contact is still important for B2B clients. Professional clients expect their purchase needs are met without leaving the office, suggesting that the role of a sales representative is still necessary and irreplaceable.

Research on B2B customers doing shopping for the needs of non-productive products, was well conducted by Forrester (2014). The study was carried out on a sample of 1,500 employees in companies employing more than 500 people in Australia, China, France, Germany, the USA and Great Britain. Research shows that the majority of purchases $(76 \%)$ are performed by searching the offer and acceptance of superiors. In these cases, there are no formal procedures for purchasing goods or service. Nearly $36 \%$ of purchases are performed through internal shopping portals, while $47 \%$ of respondents admitted that they are used to certain restrictions as far as the freedom to purchase in the market is concerned. A large group of respondents $(66 \%)$ admitted that before the purchase, there is made an on-line diagnosis, and 59\% of buyers use the predefined list of suppliers or even specific products. Over 55\% of employees surveyed expected an increase in the purchases performed using the Internet. This is facilitated by a variety of payment methods which they can use.

\subsection{Creating value in the process of $B 2 B$ sales}

The presented research results emerging a set of values cherished by B2B customers. Respondents also answered the question "What is most important in post-sale?". In the first place it was indicated the response time $(85 \%)$, whereas the professional service $(63 \%)$ comes second. So, professional clients appreciate the service time, personal relationships and professional sellers. The role of retailers also confirms answers to 


\section{IJSR} 5 questions about preferred method of contact (telephone to contact a sales representative or by e-mail).

Marketplanet (2014) conducted a survey among purchasing managers and sales managers using the portals to offer products and make a purchase for business purposes. The study was aimed at presenting the most important elements in cooperation between buyers and sellers in the area of value creation. Key findings from the survey are summarized in Table 4.

The results show good consistency in the perception of cooperation or how to use online tools for buyers and sellers. Perhaps the market is so transparent and open and mutual relationships between buyers and sellers in the professional market created common perception of value and a kind of business empathy. Buyers need the corporate value of the well-known brands, low prices and a positive shopping experience. In addition, they expect good quality product data, quick service and transparent delivery costs. Motivating factor is also the option of tracking. What prompts B2B customers to repeat purchases, is the low price and the total evaluation of the quality of service.

\begin{tabular}{|c|c|c|}
\hline Question & The answer - Buyers & The answer - Suppliers \\
\hline Supplier selection criteria & $\begin{array}{l}\text { 1. Service quality } \\
\text { 2. Service price } \\
\text { 3. Total cost of ownership }\end{array}$ & $\begin{array}{l}\text { 1. Price of services } \\
\text { 2. Quality of services } \\
\text { 3. Supplier experience }\end{array}$ \\
\hline $\begin{array}{l}\text { What is crucial in the } \\
\text { selection of a supplier? }\end{array}$ & $\begin{array}{l}\text { 1. Company strategic goals realisation } \\
\text { 2. Possibility of creating long-term } \\
\text { relationships } \\
\text { 3. Transparency }\end{array}$ & \\
\hline $\begin{array}{l}\text { Areas of cooperation in } \\
\text { value creation process }\end{array}$ & $\begin{array}{l}\text { 1. Cost reduction } \\
\text { 2. Innovativeness } \\
\text { 3. Reduced cost of components } \\
\text { (i.e. e-invoice) }\end{array}$ & $\begin{array}{l}\text { 1. Reduced cost of components } \\
\text { 2. Long-term relationships } \\
\text { 3. Innovativeness }\end{array}$ \\
\hline $\begin{array}{l}\text { Methods of common value } \\
\text { creation }\end{array}$ & $\begin{array}{l}\text { 1. Cooperation in common innovative } \\
\text { solutions preparation }\end{array}$ & $\begin{array}{l}\text { 1. Improving the process of key customers } \\
\text { service }\end{array}$ \\
\hline $\begin{array}{l}\text { The search for an offer } \\
\text { provider }\end{array}$ & $\begin{array}{l}\text { 1. Internet search engine } \\
\text { 2. Electronic request for tenders } \\
\text { 3. Business portals }\end{array}$ & $\begin{array}{l}\text { 1. Search Engine Positioning } \\
\text { 2. Social media } \\
\text { 3. Business and industry sites }\end{array}$ \\
\hline $\begin{array}{l}\text { Desired functionality of an } \\
\text { electronic marketplace for } \\
\text { companies }\end{array}$ & $\begin{array}{l}\text { 1. Categorized database provider } \\
\text { 2. Certification provider in bed }\end{array}$ & $\begin{array}{l}\text { 1. Access to the global market } \\
\text { 2. Electronic inquiries }\end{array}$ \\
\hline Use of social media & $\begin{array}{l}\text { 1. For the supplier evaluation } \\
\text { 2. To get the information } \\
\text { 3. Faster communication }\end{array}$ & $\begin{array}{l}\text { 1. Assessment of partner } \\
\text { 2. Use of information on the web } \\
\text { 3. Fast communication with partner }\end{array}$ \\
\hline
\end{tabular}

Table 4.

Results of B2B buyers and sellers research 


\subsection{Brand influence on the purchasing decisions of $\mathrm{B} 2 \mathrm{~B}$ customers}

Brown et al. (2007) analyze the role of the brand in the process of decision-making in the context of company purchase. The authors go back to the definition of the brand formulated by Kotler (1991, p. 442), understood as a name, a set of signs and symbols, whose purpose is to distinguish the products of the seller from the products of its competitors. Products are considered to be more valuable if they belong to a particular brand. Of course, compared to the situation in which these products were devoid of brand (Ailawadi, Lehmann and Neslin, 2003). The perception of the brand is reflected in its recognition, values and image.

Brand is particularly important in the case of purchases of complex products whose quality can not be recognized alone through an analysis of attributes or if the buyer is not willing to make such an analysis. For business customers, the situation is further complicated by management system, in which the person making the assessment of the product is assessed by the supervisor. In such a situation, there is support for the product brand, which is recognized in the industry as it was increased value for money, while giving psychological safety of those who decide to buy. Brown et al. (2007) conclude the discussion on the role of brand in the B2B procurement process in four aspects, presented in Table 5. The authors point out several times on the situational context of individual and group purchasing decision, as well as their consequences.

\begin{tabular}{lll}
\hline Context & Type of risk & Description \\
\hline $\begin{array}{l}\text { The organizational } \\
\text { context }\end{array}$ & $\begin{array}{l}\text { The risk of a decision of an } \\
\text { individual and a group }\end{array}$ & $\begin{array}{l}\text { Recognizable brand with an appropriate reputation with less perceived } \\
\text { risk of making the wrong decision, so in the sense of individual } \\
\text { responsibility and the whole team. }\end{array}$ \\
\hline $\begin{array}{ll}\text { The psychological } \\
\text { context }\end{array}$ & $\begin{array}{l}\text { The risk of economic } \\
\text { decisions and efficiency } \\
\text { costs }\end{array}$ & $\begin{array}{l}\text { Brand can reduce the risk of purchasing decision if you communicate } \\
\text { the arguments of rational choice of the product by reducing or proper } \\
\text { balancing the emotional components of motivation. }\end{array}$ \\
\hline $\begin{array}{l}\text { The product } \\
\text { context }\end{array}$ & $\begin{array}{l}\text { Risk relationships with } \\
\text { clients }\end{array}$ & $\begin{array}{l}\text { Brand communication should take into account the use of the product } \\
\text { by the company in activities that maintain and strengthen its market } \\
\text { position and final customer satisfaction. }\end{array}$ \\
\hline $\begin{array}{l}\text { The marketing } \\
\text { context }\end{array}$ & $\begin{array}{l}\text { Risk of ordinariness, risk } \\
\text { of use difficulties }\end{array}$ & $\begin{array}{l}\text { Brand should ensure its customers treating them in a unique way. On the } \\
\text { one hand, it should communicate the uncompromising quality in solving } \\
\text { the problem, the ease of use within the company, a friendly attitude and } \\
\text { a unique perceiveness of provider as a bidder. }\end{array}$ \\
\hline
\end{tabular}

Source: Own calculations based on Brown et al. (2007).

\section{Conclusions}

The Internet provides a wealth of information on the market for professional B2B. However, it is often imprecise. Nevertheless, based on the analysis of research findings presented above, we can draw some important conclusions regarding the emerging model of e-commerce B2B and the values, cherished by customers in the process of $\mathrm{B} 2 \mathrm{~B}$ purchasing e-commerce. They were characterized below.
B2B Customers Buying Behavior
Table 5.

Four contexts of risk reduction by proper use of the brand in the $\mathrm{B} 2 \mathrm{~B}$

business 
IJSR 5

1. The role of the Internet in B2B activities. It seems that the direction of the increasing use of electronic means of cooperation between the companies continues to grow in strength and dynamics. With the change of generations of buyers and sellers' extensive use of the network in the whole range of available forms, it will penetrate to the companies and include more and more new areas of application.

2. One-to-many, many-to-many. It seems that the distribution model, where the supplier runs his B2B shop, maintains its position only in case of strong market players. Small and weak players will not be able to get enough popularity and traffic. In this case, the model quickly quelled growing popularity of the universal (marketplace), such as e.g. Amazon and Alibaba, who are reporting double-digit increases in turnover year-on-year (Forbes, 2016; Internetretailer, 2014).

3. Global market vs local market. Trading platforms such as Amazon, Alibaba, eBuy, or Allegro will play a large role in the purchasing of non-production, and the search for new suppliers. It seems that this way of realization of purchases will not have decisive significance for purchasing professionals. They require continuous and specialist contact and the relationship between buyers and sellers. These relationships and proven ways of cooperation form the basis of contracts for the professional market. Of course, geographical proximity and cultural diversity may lose value or even cease to be important in the process of purchasing.

4. Blurring differences in individual and business customer experience. Business customers in everyday life are consumers. In shopping for the needs of corporate accept service of similar quality, while others require a specialized approach. One of the key areas specific to B2B relationships is an individual pricing system. Business customers accept the differences in prices for different customers and even require differentiation. Companies usually combine the price with the volume and repeatability purchases. B2B customers are demanding payment for their loyalty in the form of a good price, or special handling facilities and automation (e.g. EDI). They strive to optimize costs. Proffesional customers expect a detailed technical description of the product. At the same time, retail customers expect photos, graphics and synthetic description of the technical characteristics and utility of the product.

5. Multichanneling. For B2B customers transition to the electronic channel will increase. Professional clients are often equipped with several devices with Internet access, so access from each of them to the purchasing platform can be accepted with appreciation. However, not all of them will be used for immediate purchases. Often, because they are used to verify the nature, availability or price of the goods. Many customers, even professional shopping companies, consider it a too serious step to carry it out on one's smartphone, in a coffee shop, or while travelling. Undoubtedly, however, B2B clients will not have any inhibitions to use all channels of communication and identify the offer, including salespeople, call center and shop stationary supplier.

6. Self-service with everything. The appetite for reducing servicing costs will rise. Providers will pass on to buyers and systems, most actions that they can perform by themselves. This will allow access to products, but with limited service in the use of personnel through a call center or a unit dedicated to key customers. The sales 
force will be transferred to the task of acquiring new customers, leaving regular customers in electronic self-service. More discussion on this topic can be found in the article by Johnson (2016).

7. Scope of the offer. Most professional customers look for specific products. They do not need a wide range, but a trusted source of specified ranges.

8. The role of trademark. In the process of $\mathrm{B} 2 \mathrm{~B}$, brand is of particular importance. It constitutes a kind of insurance in case of errors in purchasing decisions. On the one hand, "support" of the decision on buying a product with a good tradmark results in the success of product's usage, on the other hand, recognized brand with a stable market position does not leave the company itself in case of implementation of difficulties. In such situations, you can take advantage of the seller's experience and flexibility behind the product brand.

Despite the popularity of the idea that e-commerce systems for professional clients may be downloaded from the retail market, a closer examination of the B2B market, even on the basis of the online publication, reveals significant differences. Professional clients will expect specific treatment and sales systems take into account their requirements (see e.g. Parry, 2015).

\section{References}

Ailawadi, K. L., Lehmann, D. R. and Neslin, S. A. (2003). Revenue Premium as an Outcome Measure of Brand Equity, Journal of Marketing, Vol. 67, pp. 1-17.

Bałkowiec, M. (2015). Report: Almost Half of the Companies in the B2B Multi-Channel Selling. Retrived November 10, 2016 from: http://evigo.pl/14619-raport-prawie-polowa-firm-z-sektorab2b-sprzedaje-wielokanalowo/

Belcik, A., (2014). What is Omnichannel, Puls Biznesu. Retrieved September 20, 2016 from: http:// www.pb.pl/3886374,60927,co-to-jest-omnichannel

Brown, B. P., Bellenger, D. N. and Johnston, W. J. (2007). The Implications of Business-to-Business and Consumer Market Differences for B2B Branding Strategy, Journal of Business Market Management, Vol. 1, No. 3, pp. 209-230.

Deloitte, (2015). Omni-Channel Retail, A Deloitte Point of View. Retrieved October 10, 2016 from: https://www2.deloitte.com/content/dam/Deloitte/se/Documents/technology/Omni-channel -2015.pdf

Ecommerce Foundation, (2016a). E-commerce Association Europe Data at a Glance 2015. Retrieved from: https://www.ecommercewiki.org/wikis/www.ecommercewiki.org/images/2/25/European B2C_Ecommerce_Report_2016.pdf

Ecommerce Foundation, (2016b). Key B2C E-Commerce Date of Goods and Service at a Glance 2016. Retrieved from: https://www.ecommercewiki.org/Prot:Global_B2C_Ecommerce_Report 2016

E-Commerce Poland, (2015). Trends in B2B Sales in Poland 2015. Retrieved October 25, $201 \overline{6}$ from: $\mathrm{http} / /$ www.ecommercepolska.pl/pl/o-nas/aktualnosci/listopad-2015/trendy-w-sprzedazy-b2b-wpolsce-najnowszy -raport-e-chamber /

eMarketer, (2016). Retrieved from: https://www.emarketer.com/Articles/Print.aspx?R=1014369 and https://www.emarketer.com/Article/UPS-Executives-on-B2B-Ecommerce/1014422

Forbes, (2016). Retrieved from: www.forbes.com/sites/xiangwang/2016/11/02/alibaba-reports-55revenue-growth-ready-for-singles-day-battle/\#331340bf2d4c

Forrester, (2014). The Rise of the Empowered B2B End User Buyer. Retrieved October 20, 2016 from: http://www.intershop.com/files/Intershop/media/downloads/en/studies/2014-Forrester-TheRise-of-the-Empowered- B2B-End-User-Buyer.pdf
B2B Customers

Buying Behavior 
IJSR 5

Forrester, (2015). Mastering Omni-Channel B2B Customer Engagement. Retrieved October 25, 2016 from: https://www.accenture.com/t20151103T043512_w_/us-en/_acnmedia/ Accenture/Conversion-Assets/DotCom/Documents/Global/PDF/Digital_3/ĀccentureMastering- Omni-Channel-B2B-Customer-Engagement-report.pdf

Forte, D. (2014). Five Best Practices for B2B Mobile Commerce. Retrieved October 24, 2016 from: http://multichannelmerchant.com/infographics/five-best-practices-for-b2b-mobile-commerce04082014/

Frost \& Sullivan, (2015). The Global Market for Electronic B2B Sales Income Will Reach 6.7 Trillion US Dollars in 2020. Retrieved November 7, 2016 from: http://ww2.frost.com/news/ press-releases/frost-sullivan-globalny-rynek-elektronicznej-sale-b2b-reaches-Income-onthe-level-67-trillion-usd-in-2020-r /

Internetretailer, (2014). Retrieved from: http://www.internetretailer.com/2014/07/22/amazon-andebay-grow-their-b2b-online-sales

Johnson, M. (2016). Predictions 2016: The Year of the Business-to-Business Customer. Retrieved October 30, 2016 from: http://www.sdcexec.com/article/12159594/2016-predictions-the-yearof-the-business-to- business-customer

Kaplan, M. (2015). B2B Ecommerce Growing; Becoming More Like B2C. Retrieved November 10, 2016 from: http://www.practicalecommerce.com/articles/85970-B2B-Ecommerce-GrowingBecoming-More-Like-B2C

Kotler, P. and Armstrong, G. (1991). Principles of Marketing, Prentice Hall, Englewood Cliffs, N.J.

Laskowski, M. and Poszewicki, A. (2015). E-Commerce Market and Perspectives for the Reverse Commerce, Contemporary Economy Electronic Scientific Journal, Vol. 6, No. 4, pp. 39-55.

Lazaris, C. and Vrechopoulos, A. (2014). From Multi-Channel Is "Omnichannel" Retailing: Review of the Literature and Calls for Research; the $2^{\text {nd }}$ International Conference on Contemporary Marketing Issues, (ICCMI).

Lingqvist, O., Plotkin, C. L. and Stanley, J. (2015). Do You Really Understand How Your Business Customers Buy?, McKinsey Quarterly. Retrieved December 15, 2016 from: http://www. mckinsey.com/business-functions/marketing-and-sales/our-insights / do-you-really-understandhow-your-business-customers-buy

Malinowski, A. and Senkus, P. (2015). Business to Business Market in Poland-Range and Growth Prospects. Scientific Papers of the University of Natural Sciences and Humanities in Siedlce, Series: Administration and Management, Vol. 33.

Marketplanet, (2014). Retrieved November 20, 2016 from: http://www.marketplanet.pl/raporty/ kupiec-dostawca-kreatorami-wartosci/

Orrigo, M. (2015). 9 Amazing Facts About B2B Mobile Commerce. Retrieved October 24, 2016 from: https://www.handshake.com/blog/mobile-commerce-b2b-facts/

Parry, T. (2015). B2B Ecommerce Can Not Completely Copy Its B2C Counterparts. Retrieved October 30, 2016 from: http://multichannelmerchant.com/marketing/b2b/b2b-ecommerce-cantcompletely-copy-its-b2c-counterparts-12082015/

Rutkowski, M. and Górazda, M. (2016). O-Omnichannel. Retrieved October 12, 2016 from: http:// nowymarketing.pl/a/10116,o-omnichannel-encyklopedia-marketingu

Snyder, K. and Hilal P. (2015). The Changing Face of B2B Marketing. Retrieved October 30, 2016 from: https://think.storage.googleapis.com/docs/the-changing-face-b2b-marketing.pdf

Statista, (2016). Global Mobile Data Traffic Forecast. Retrieved October 28, 2016 from: https:// www.statista.com/statistics/271405/global-mobile-data-traffic-forecast/

Traxpay Team, (2015). B2B E-Commerce: The Influence B2c. Retrieved November 10, 2016 from: http://traxpay.com/2015/08/b2b-e-commerce-the-b2c-influence/

UNCTAD, (2016). New Initiative to Help Developing Countries Grasp \$22 Trillion E-Commerce Opportunity. Retrieved November 6, 2016 from: http://unctad.org/es/paginas/newsdetails. 
aspx?OriginalVersionID=1281\&Sitemap_x0020_Taxonomy=Information $\% 20$ and $\% 20$ Communication\%20Technologies

Unity, (2014). Report on the State of Omnichannel Commerce in Poland. Retrieved November 10,

B2B Customers Buying Behavior 2016 from: http://evigo.pl/9504-grupa-unity-jak-sprzedawcy-wdrazaja-model-omni-channel/

Ważyńska, D. (2015). How to Effectively Use the Smart Wi-Fi in Your Restaurant? Retrieved September 20, 2016 from: https://socialwifi.com/pl/kilka-slow-o-inteligentnym-wi-fi-w-strategiiomnichannel/?gclid=CJ_C3JTP588CFRa3Gwod6F8Eag

Webster Jr., F. E. and Wind, Y. (1972). A General Model for Understanding Organizational Buying Behavior, The Journal of Marketing, Vol. 36, No. 2, pp. 12-19.

Wieczerzycki, M. (2013). Reinterpretation Dichotomy Marketing B2B and B2C in the Light of Modern Marketing Theory, Marketing and Market, Vol. 7, No. 20, pp. 9-16.

Yenna, A. (2015). Borrow B2C Website Features to Enhance Your B2B Ecommerce Site. Retrieved October 10, 2016 from: http://multichannelmerchant.com/marketing/b2b/borrow-b2c-websitefeatures-to-enhance-your-b2b-ecommerce-site-16112015/ 